\title{
THE EFFICACY OF CRISPR-CAS9-MEDIATED INDUCTION OF THE CCR5DELTA32 MUTATION IN THE HUMAN EMBRYO
}

Kodyleva TA1 ${ }^{1}$, Kirillova AO ${ }^{1}$, Tyschik EA ${ }^{1}$, Makarov $W^{2}$, Khromov AV², Gushchin VA², Abubakirov AN ${ }^{1}$, Rebrikov DV ${ }^{1,3 凶}$, Sukhikh GT $^{1}$

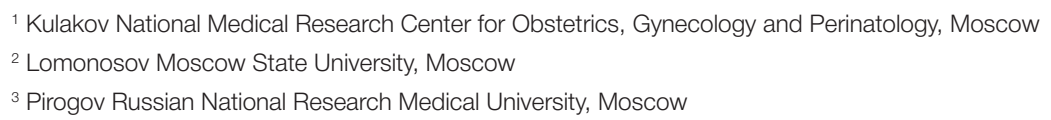

\begin{abstract}
The editing of the CCR5 gene in the CD4+ $\mathrm{T}$ cell genome is an effective way of preventing HIV-1 proliferation. Very similar strategies can be used to protect the fetus of an HIV-infected female showing a weak response to antiretroviral therapy. Inducing the "natural" CCR5delta32 mutation in a zygote may guard the fetus against HIV infection both in utero and at birth. In this study, we optimize the CRISPR-Cas9 system to induce a homozygous 32-nt deletion similar to the naturally occurring CCR5delta32 allele in the human zygote at the S-phase. Edits were done in the abnormal tripronuclear zygotes unsuitable for IVF. Sixteen tripronuclear zygotes in the S-phase obtained from WT CCR5 donors were injected with an original CRISPR-Cas9 system designed by the authors. Upon injection, the zygotes were transferred into the Blastocyst (COOK) embryo culture medium and cultured for 5 days in a $\mathrm{CO}_{2}$ incubator until blastocysts were formed (approximately 250 cells). Eight zygotes that successfully developed into blastocysts were PCR-genotyped to analyze the efficacy of genome editing. Of 16 zygotes injected with CRISPR-Cas9, only 8 reached the blastocyst stage. PCR genotyping revealed the absence of the initial WT CCR5 variant in 5 of 8 blastocysts (100\% CCR5delta32 homozygous). Two had about 3\% and one about $20 \%$ of WT CCR5 mosaicism. This leads us to conclude that the efficacy of the proposed CRISPR-Cas9 system for the induction of the CCR5delta32 mutation in human embryos is very high producing more than $50 \%$ of completely modified embryos.
\end{abstract}

Keywords: CRISPR-Cas9, genome editing, human embryo, CCR5, CCR5delta32, HIV resistance

$\square$ Correspondence should be addressed: Denis V. Rebrikov

Ostrovityanova 1, Moscow, 117997; drebrikov@gmail.com

Received: 26.09.2018 Accepted: 09.10.2018

DOI: 10.24075/brsmu.2018.052

\section{ЭФФЕКТИВНОСТЬ СОЗДАНИЯ ДЕЛЕЦИИ CCR5DELTA32 МЕТОДОМ CRISPR-CAS9 В ЭМБРИОНАХ ЧЕЛОВЕКА}

Т. А. Кодылева 1 , А. О. Кириллова', Е. А. Тыщик¹, В. В. Макаров², А. В. Хромов², В. А. Гущин², А. Н. Абубакиров¹, Д. В. Ребриков ${ }^{1,3 \otimes}$, Г. Т. Сухих ${ }^{1}$

${ }^{1}$ Национальный медицинский исследовательский центр акушерства, гинекологии и перинатологии имени В. И. Кулакова, Москва

${ }^{2}$ Московский государственный университет имени М. В. Ломоносова, Москва

${ }^{3}$ Российский национальный исследовательский медицинский университет имени Н. И. Пирогова, Москва

Изменение гена CCR5 путем редактирования генома CD4+-Т-клеток является одним из способов предотвращения распространения ВИЧ-1-инфекции. Однако похожая стратегия защиты от ВИЧ может быть использована и для защиты плода ВИЧ-инфицированных женщин со слабым ответом на антиретровирусную терапию. Создание «естественного» аллеля CCR5delta32 на стадии зиготы может защитить плод от ВИЧ-инфекции во время внутриутробного развития и родов. Целью данного исследования была оптимизация системы CRISPR-Cas9 под создание гомозиготной 32-нуклеотидной делеции (аналогичной природному варианту CCR5delta32) в S-фазе зиготы человека. Для редактирования генома были использованы зиготы с аномальным числом пронуклеусов (более двух), непригодные для ЭКО. 16 аномальных зигот от доноров с WT CCR5 были инъецированы разработанной системой CRISPR-Cas9 в S-фазе. После инъекции зиготы помещали в культуральную среду Blastocyst (COOK) и культивировали в течение 5 дней в $\mathrm{CO}_{2}$-инкубаторе до стадии бластоцисты (приблизительно 250 клеток). Для анализа эффективности редактирования генома 8 успешно развивавшихся эмбрионов были генотипированы методом полимеразной цепной реакции (ПЦР). Из 16 зигот, инъецированных системой CRISPR-Cas9, лишь 8 достигли стадии бластоцисты. ПЦР-генотипирование показало отсутствие исходного варианта WT CCR5 в 5 из 8 бластоцист (100\% гомозиготы по CCR5delta32). Два эмбриона продемонстрировали около 3\% и один - около 20\% мозаицизма по WT CCR5. Таким образом, эффективность разработанной CRISPR-Cas9 системы для создания аллеля CCR5delta32 в эмбрионах человека довольно высока: более половины эмбрионов оказываются полностью модифицированными.

Ключевые слова: CRISPR-Cas9, редактирование генома, эмбрион человека, CCR5, CCR5delta32, устойчивость к BИ4

$\triangle$ Для корреспонденции: Денис Владимирович Ребриков

ул. Островитянова, д. 1, г. Москва, 117997; drebrikov@gmail.com

Статья получена: 26.09.2018 Статья принята к печати: 09.10.2018

DOI: 10.24075/vrgmu.2018.052

In the past few years the rapid evolution of CRISPR-based technologies has expanded their application scope and paved their way to preclinical trails. The successful editing of the CD4+
T cell genome by either knocking out or modifying the gene encoding the chemokine receptor CCR5 has raised new hope for the true functional cure of HIV-1 infection [1-5]. 
Apart from the edits in the CCR5-encoding gene of T cells that block the development of AIDS in HIV-infected patients, genome editing techniques can be used to induce the CCR5delta32 mutation in the egg as part of in vitro fertilization (IVF) procedures to protect the fetus of an HIV-infected female showing a weak response to antiretroviral therapy [6, 7].

Injecting CRISPR-Cas9 components into the zygote will entail genome modifications in almost all cells of the organism, which has already been demonstrated for a few deleterious hereditary mutations [8-12]. Importantly, the edited genome will be passed on to subsequent generations.

A modification identical to the naturally occurring mutant allele CCR5delta32 can be expected to protect the fetus from HIV infection in utero and at childbirth. Another beneficial effect of this edit is a potential lifelong immunity to HIV.

In this study we optimize the CRISPR-Cas9 system to induce a homozygous 32-nt deletion similar to the mutant CCR5delta32 allele in the human zygote during the S-phase. Editing was performed on the abnormal tripronuclear zygotes unsuitable for IVF.

\section{METHODS}

\section{Ethical approval and consent to participate}

The study protocol was reviewed and approved by the Ethics Committee of Kulakov National Medical Research Center for Obstetrics, Gynecology and Perinatology (Approval Reference: No.2017/45). The study complied with the international guidelines for human embryo research. Written informed consent was obtained from each couple before they could donate tripronuclear zygotes. Only homozygous wild-type CCR5 pairs were included in the study.

\section{Zygote collection procedures}

Tripronuclear zygotes were donated by patients undergoing IVF treatment from September 2017 through April 2018 at Kulakov National Medical Research Center for Obstetrics, Gynecology and Perinatology (Moscow, Russia). In total, 21 tripronuclear zygotes were obtained from 11 couples, of which 16 were injected with CRISPR-Cas 9 and 5 were used as a control.

\section{Design, synthesis and in vitro activity of gRNAs}

Guide RNAs (gRNAs) were designed to match the target locus of wild-type (WT) CCR5 and CCR5delta32 alleles from the National Center for Biotechnology Information database (USA) were used to design guide RNAs (gRNAs). A 200 bp-long DNA sequence was picked for further editing in which the sites for base pairing between gRNA and target DNA were selected adjacent to the PAM sequence (Fig. 1). In total, 9 gRNAs were designed to target the sites convenient for the subsequent homologous repair of double-stranded breaks (Table 1).

The transcription template was generated by pairwise annealing of primers (Evrogen; Russia) and PCR-amplified by Taq polymerase (Evrogen; Russia). Guide RNA was synthesized from the template using T7 RNA polymerase (SybEnzyme; Russia).

The activity of the resulting gRNAs was studied using a test plasmid coding for the wild-type CCR5 sequence. In vitro

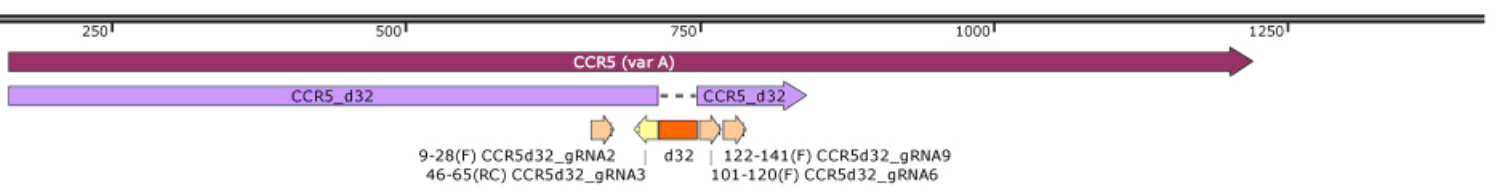

16-35(RC) CCR5d32_gRNA1
$95-114$ (F) CCR5d32_9RNA4

¿ ל

97-116(F) CCR5d32_QRNAS 132-151(RC) CCR5d32_9RNA8

Fig. 1. gRNAs layout inside the human CCR5 gene

Table 1. Oligos for gRNA and DNA patches

\begin{tabular}{|c|c|}
\hline CCR5_BamHI_F & GGATCCTAGGTACCTGGCTGTCGTCCATG \\
\hline CCR5_Xbal_R & TCTAGAATGCAGCAGTGCGTCATCC \\
\hline CCR5d32_gRNA1 & TAATACGACTCACTATAGGAAGACCTTCTTTTGAGATCGTTTAGAGCTAGAAATAGCAAG \\
\hline CCR5d32_gRNA2 & TAATACGACTCACTATAGGTTTACCAGATCTCAAAAAGAGTTTTAGAGCTAGAAATAGCAAG \\
\hline CCR5d32_gRNA3 & TAATACGACTCACTATAGGGTATGGAAAATGAGAGCTGCGTITAGAGCTAGAAATAGCAAG \\
\hline CCR5d32_gRNA4 & TAATACGACTCACTATAGGGACATTAAAGATAGTCATCTGTTITAGAGCTAGAAATAGCAAG \\
\hline CCR5d32_gRNA5 & TAATACGACTCACTATAGGACATTAAAGATAGTCATCTTGTTTTAGAGCTAGAAATAGCAAG \\
\hline CCR5d32_gRNA6 & TAATACGACTCACTATAGGAAAGATAGTCATCTTGGGGCGTTITAGAGCTAGAAATAGCAAG \\
\hline CCR5d32_gRNA7 & TAATACGACTCACTATAGGTGACCATGACAAGCAGCGGCGTTITAGAGCTAGAAATAGCAAG \\
\hline CCR5d32_gRNA8 & TAATACGACTCACTATAGGCAGATGACCATGACAAGCAGGTTTTAGAGCTAGAAATAGCAAG \\
\hline CCR5d32_gRNA9 & TAATACGACTCACTATAGGGGTCCTGCCGCTGCTTGTCAGTTTTAGAGCTAGAAATAGCAAG \\
\hline CCR5_big_leftpart_F & САACTCTTGACAGGGCTCTATTTTATAGGC \\
\hline CCR5_big_leftpart_R & GGACCAGCCCCAAGATGACTATCTTTAATGTATGGAAAATGAGAGCTGCAGGTGTAA \\
\hline CCR5_big_rightpart_R & GCATAGCTTGGTCCAACCTGTTAG \\
\hline CCR5_gib_rightpart_F & TTAAAGATAGTCATCTTGGGGCTGGTCC \\
\hline CCR5_small_F & GTGATCACTTGGGTGGTGGC \\
\hline CCR5_small_R & TTAGGATTCCCGAGTAGCAGATGAC \\
\hline CCR5_small_hairpin_R & GCTAAGCGGGTGGGACTTCCTAGTCCCACCCGCTTAGGATTCCCGAGTAGCAGATGAC \\
\hline
\end{tabular}


DNA cleavage by the complex formed by RNA and EnGen ${ }^{\circledast}$ Cas9 NLS (New England Biolabs; USA) was performed as recommended by the manufacturer of the enzyme. The best results were shown by gRNAs \#1 and \#5, which were subsequently used for in vivo experiments mixed at a 1:1 ratio.

\section{DNA patch}

A standard overlap extension PCR technique was used to obtain a DNA patch. After the construct was assembled, a shorter single-stranded DNA product (perfect for promoting recombination over non-homologous end joining NHEJ) was amplified by asymmetric PCR with one of the primers (index F) used in excess. The resulting fragment reads as follows: GTGATCACTTGGGTGGTGGCTGTGTITGCGTCTCT CCCAGGAATCATCTITACCAGATCTCAAAAAGAAGGTCTTC ATTACACCTGCAGCTCTCATITCCATACATTAAAGATAGTCA TCTTGGGGCTGGTCCTGCCGCTGCTTGTCATGGTCATCTG CTACTCGGGAATCCTAA

\section{Preparation of RNP complexes}

The following components were used to prepare RNP complexes: Cas9 $(20 \mu \mathrm{M})$, a mix of gRNA\#1 and gRNA\#5 at a ratio of 1:1 (30 $\mathrm{ng} / \mathrm{\mu l})$, ssDNA (100 $\mathrm{ng} / \mathrm{\mu l})$, a dilution buffer (0.25 mM EDTA/10 mM TrisHCl, pH 7.4).

The injectable solution was prepared by mixing $0.5 \mu$ of Cas 9 $(20 \mu \mathrm{M})$ with $4.5 \mu \mathrm{l}$ of the dilution buffer. Then, $1.56 \mu \mathrm{l}$ of Cas9 $(2 \mu \mathrm{M}), 0.6 \mu$ of the gRNA mix (30 ng/ $\mathrm{l})$ and $2.5 \mu \mathrm{lssDNA}(100 \mathrm{ng} / \mathrm{\mu l})$ were combined with $5.34 \mu \mathrm{l}$ of the dilution buffer. The mix was incubated at $37^{\circ} \mathrm{C}$ for 10 min and immediately used for injecting.

\section{Injection of CRISPR-Cas9}

The CRISPR-Cas9 complex was injected into tripronuclear zygotes in the S-phase according to the standard Intracytoplasmic Sperm Injection (ICSI) protocol [13]. The injection volume was $1 \mathrm{nl}$. After the injection, the zygotes were washed twice in the Sydney IVF Cleavage Medium (COOK Medical LLC; USA), then moved into the Sydney IVF Blastocyst Medium (COOK Medical LLC; USA) and incubated in the EmbryoPlan $\mathrm{CO}_{2}$ Incubator (West trade LLC; Russia) under standard conditions for 5 days until blastocysts were formed (about 250 cells). Upon incubation each blastocyst was transferred into $12 \mu \mathrm{l}$ of the dilution buffer and immediately analyzed by PCR.

\section{PCR genotyping and data analysis}

Genotyping by double-tube PCR was performed in the DTprime Real-Time PCR Cycler (DNA-Technology, Russia) as described in [14], but to exclude the gRNA region, another universal primer CCR5_check2_R was used with the following sequence: TCATTTCGACACCGAAGCAGA. PCR data were analyzed in the DTprime Real-Time PCR Cycler Software v.7.7 (DNA-Technology; Russia).

\section{RESULTS}

Of 16 zygotes injected with the CRISPR-Cas9 complex only 8 reached the blastocyst stage, whereas of 5 control zygotes injected with the dilution buffer 3 developed into a blastocyst. This is the standard rate of blastocyst formation for abnormal zygotes, meaning that the injection did not increase the risk of aborted development. PCR genotyping revealed the absence of the initial WT CCR 5 variant in 5 of 8 blastocysts, so those embryos were $100 \%$ CCR5delta32- homozygous. Two embryos demonstrated about 3\% and one about 20\% of WT CCR5 mosaicism (Fig. 2). Cp values for each embryo are presented in Table 2. For each negative control sample (dilution buffer) each PCR was performed in two replicates. The reaction yielded no PCR products.

\section{DISCUSSION}

CRISPR-Cas9-mediated editing of the human zygote is an effective method for intracellular DNA modification capable of eliminating nearly $100 \%$ of the initial sequence in more than half of embryos
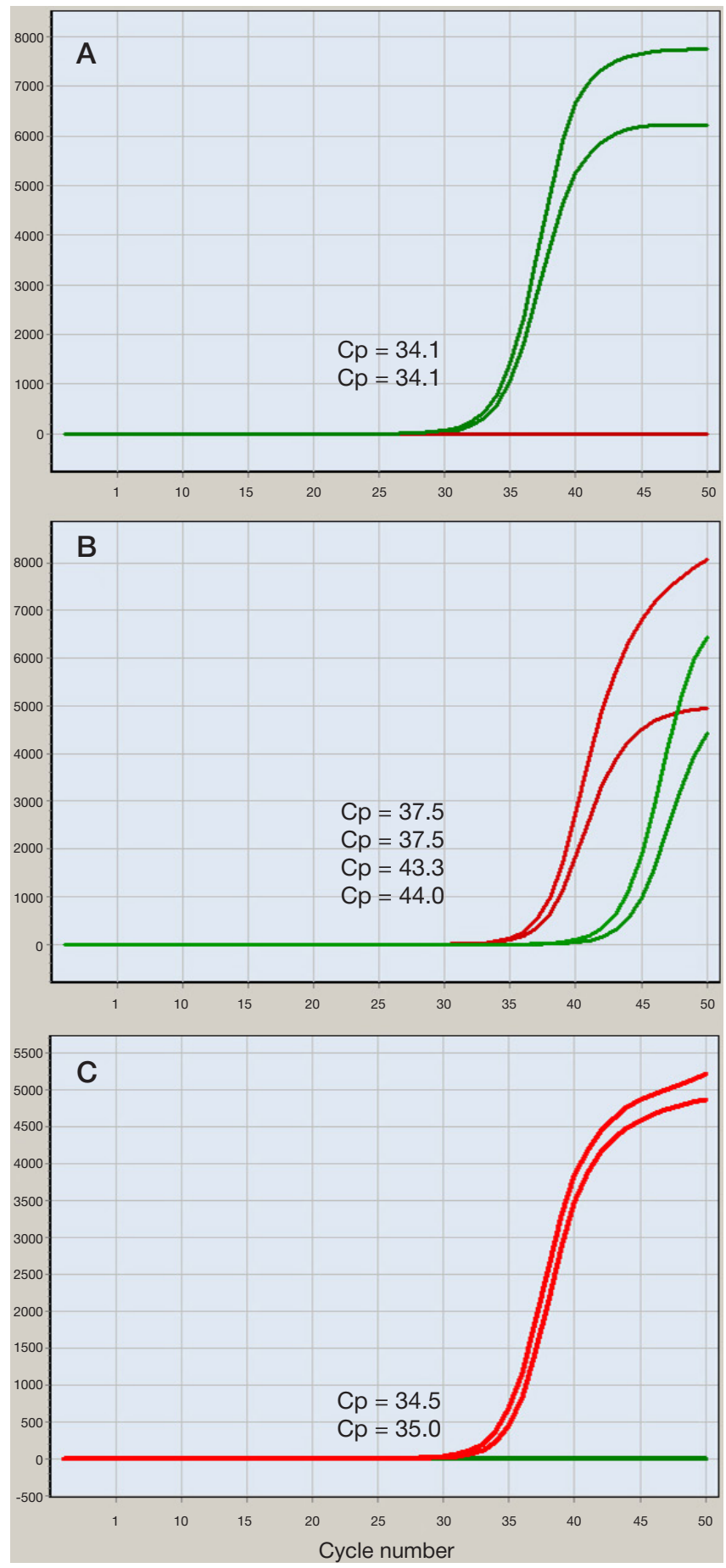

Fig. 2. Examples of real-time PCR curves for different genotypes: $A-$ two control embryos, B - two mosaic embryos with about 3\% of WT CCR5, C - two CCR5delta32 homozygous embryos 
Table 2. Real-time PCR Cp values for each embryo

\begin{tabular}{|l|c|c|}
\hline \multicolumn{1}{|c|}{ Embryo № } & Cp WT & Cp del \\
\hline Control 1 & 34.1 & - \\
\hline Control 2 & 34.1 & - \\
\hline Control 3 & 36.0 & 38.1 \\
\hline Exp 1 & - & 38.1 \\
\hline Exp 2 & 40.8 & 37.8 \\
\hline Exp 3 & & 37.5 \\
\hline Exp 4 & 44.0 & 37.3 \\
\hline Exp 5 & - & 37.5 \\
\hline Exp 6 & 43.3 & 34.5 \\
\hline Exp 7 & - & 35.0 \\
\hline $\operatorname{Exp~8~}$ & - & \\
\hline
\end{tabular}

Note: - no PCR products.

$[9,10,12,15]$. Our results are well correlated with those yielded by other GE-system models demonstrating very high efficacy.

In the past few years we have witnessed the rapid evolution of GE-systems. However, the off-target activity of such GEsystems still remains a challenge. Genome editing techniques can be introduced into clinical practice only if they have been proved to be safe for the patient.

\section{References}

1. Yu S, Yao Y, Xiao H, Li J, Liu Q, Yang Y, et al. Simultaneous Knockout of CXCR4 and CCR5 Genes in CD4+ T Cells via CRISPR-Cas9 Confers Resistance to Both X4- and R5-Tropic Human Immunodeficiency Virus Type 1 Infection. Hum Gene Ther. 2018 Jan; 29 (1): 51-67. DOI: 10.1089/hum.2017.032.

2. Xu L, Yang H, Gao Y, Chen Z, Xie L, et al. CRISPR-Cas9-Mediated CCR5 Ablation in Human Hematopoietic Stem/Progenitor Cells Confers HIV-1 Resistance In Vivo. Mol Ther. 2017 Aug 2; 25 (8): 1782-9. DOI: 10.1016/j.ymthe.2017.04.027.

3. Haworth KG, Peterson CW, Kiem HP. CCR5-edited gene therapies for HIV cure: Closing the door to viral entry. Cytotherapy. 2017 Nov; 19 (11): 1325-38. DOI: 10.1016/j.jcyt.2017.05.013.

4. Liu Z, Chen S, Jin X, Wang Q, Yang K, Li C, et al. Genome editing of the HIV co-receptors CCR5 and CXCR4 by CRISPR-Cas9 protects CD4+ T cells from HIV-1 infection. Cell Biosci. 2017 Sep 9; (7): 47. DOI: 10.1186/s13578-017-0174-2.

5. Nerys-Junior A, Braga-Dias LP, Pezzuto P, Cotta-de-Almeida V, Tanuri A. Comparison of the editing patterns and editing efficiencies of TALEN and CRISPR-Cas9 when targeting the human CCR5 gene. Genet Mol Biol. 2018 Jan-Mar; 41 (1): 16779. DOI: 10.1590/1678-4685-GMB-2017-0065.

6. Makokha EP, Songok EM, Orago AA, Koech DK, Chemtai AK, Kobayashi N, et al. Maternal immune responses and risk of infant infection with HIV-1 after a short course Zidovudine in a cohort of HIV-1 infected pregnant women in rural Kenya. East Afr Med J. 2002 Nov; 79 (11): 567-73.

7. French CE, Tookey PA, Cortina-Borja M, de Ruiter A, Townsend CL, Thorne C. Influence of short-course antenatal antiretroviral therapy on viral load and mother-to-child transmission in subsequent pregnancies among HIV-infected women. Antivir Ther. 2013; 18 (2): 183-92. DOI: 10.3851/IMP2327.

\section{Литература}

1. Yu S, Yao Y, Xiao H, Li J, Liu Q, Yang Y, et al. Simultaneous Knockout of CXCR4 and CCR5 Genes in CD4+ T Cells via

\section{CONCLUSIONS}

This is the first study demonstrating the efficacy of CRISPR-Cas9-mediated induction of the CCR5delta32 mutation in the human embryo. Its efficacy is very high producing more than $50 \%$ of completely modified embryos.
8. Liang P, Xu Y, Zhang X, Ding C, Huang R, Zhang Z, et al. CRISPRCas9-mediated gene editing in human tripronuclear zygotes. Protein Cell. 2015 May; 6 (5): 363-72. DOI: 10.1007/s13238015-0153-5. Epub 2015 Apr 18.

9. Tang L, Zeng Y, Du H, Gong M, Peng J, Zhang B, et al. CRISPRCas9-mediated gene editing in human zygotes using Cas9 protein. Mol Genet Genomics. 2017 Jun; 292 (3): 525-33. DOI: 10.1007/s00438-017-1299-z.

10. Ma H, Marti-Gutierrez N, Park SW, Wu J, Lee Y, Suzuki K, et al. Correction of a pathogenic gene mutation in human embryos. Nature. 2017 Aug 24; 548 (7668): 413-19. DOI: 10.1038/ nature23305

11. Fogarty NME, McCarthy A, Snijders KE, Powell BE, Kubikova N, Blakeley P, et al. Genome editing reveals a role for OCT4 in human embryogenesis. Nature. 2017 Oct 5; 550 (7674): 67-73. DOl: 10.1038/nature24033.

12. Liang $P$, Ding $C$, Sun $H$, Xie $X, X u Y$, , Zhang $X$, et al. Correction of $\beta$-thalassemia mutant by base editor in human embryos. Protein Cell. 2017 Nov; 8 (11): 811-22. DOl: 10.1007/s13238-017-0475-6.

13. Joris H, Nagy Z, Van de Velde H, De Vos A, Van Steirteghem A. Intracytoplasmic sperm injection: laboratory set-up and injection procedure. Hum Reprod. 1998 Apr; 13 Suppl 1: 76-86.

14. Kofiadi IA, Rebrikov DV, Trofimov DY, Alexeev LP, Khaitov RM. Allelic distribution of the CCR5, CCR2, and SDF1 gene polymorphisms associated with HIV-1/AIDS resistance in Russian populations. Dokl Biol Sci. 2007 Jul-Aug; (415): 320-3.

15. Kang $X$, He W, Huang $Y, Y u$, Chen $Y$, Gao X, Sun X, Fan $Y$. Introducing precise genetic modifications into human 3PN embryos by CRISPR/Cas-mediated genome editing. J Assist Reprod Genet. 2016 May; 33 (5): 581-588. DOI: 10.1007/ s10815-016-0710-8. 
2018 Jan; 29 (1): 51-67. DOI: 10.1089/hum.2017.032.

2. Xu L, Yang H, Gao Y, Chen Z, Xie L, et al. CRISPR-Cas9-Mediated CCR5 Ablation in Human Hematopoietic Stem/Progenitor Cells Confers HIV-1 Resistance In Vivo. Mol Ther. 2017 Aug 2; 25 (8): 1782-9. DOI: 10.1016/j.ymthe.2017.04.027.

3. Haworth KG, Peterson CW, Kiem HP. CCR5-edited gene therapies for HIV cure: Closing the door to viral entry. Cytotherapy. 2017 Nov; 19 (11): 1325-38. DOl: 10.1016/j.jcyt.2017.05.013.

4. Liu Z, Chen S, Jin X, Wang Q, Yang K, Li C, et al. Genome editing of the HIV co-receptors CCR5 and CXCR4 by CRISPR-Cas9 protects CD4+ T cells from HIV-1 infection. Cell Biosci. 2017 Sep 9; (7): 47. DOI: 10.1186/s13578-017-0174-2.

5. Nerys-Junior A, Braga-Dias LP, Pezzuto P, Cotta-de-Almeida V, Tanuri A. Comparison of the editing patterns and editing efficiencies of TALEN and CRISPR-Cas9 when targeting the human CCR5 gene. Genet Mol Biol. 2018 Jan-Mar; 41 (1): 16779. DOI: 10.1590/1678-4685-GMB-2017-0065.

6. Makokha EP, Songok EM, Orago AA, Koech DK, Chemtai AK, Kobayashi N, et al. Maternal immune responses and risk of infant infection with HIV-1 after a short course Zidovudine in a cohort of HIV-1 infected pregnant women in rural Kenya. East Afr Med J. 2002 Nov; 79 (11): 567-73.

7. French CE, Tookey PA, Cortina-Borja M, de Ruiter A, Townsend CL, Thorne C. Influence of short-course antenatal antiretroviral therapy on viral load and mother-to-child transmission in subsequent pregnancies among HIV-infected women. Antivir Ther. 2013; 18 (2): 183-92. DOI: 10.3851/IMP2327.

8. Liang P, Xu Y, Zhang X, Ding C, Huang R, Zhang Z, et al. CRISPRCas9-mediated gene editing in human tripronuclear zygotes.
Protein Cell. 2015 May; 6 (5): 363-72. DOI: 10.1007/s13238015-0153-5. Epub 2015 Apr 18.

9. Tang L, Zeng Y, Du H, Gong M, Peng J, Zhang B, et al. CRISPRCas9-mediated gene editing in human zygotes using Cas9 protein. Mol Genet Genomics. 2017 Jun; 292 (3): 525-33. DOI: 10.1007/s00438-017-1299-z.

10. Ma H, Marti-Gutierrez N, Park SW, Wu J, Lee Y, Suzuki K, et al. Correction of a pathogenic gene mutation in human embryos. Nature. 2017 Aug 24; 548 (7668): 413-19. DOI: 10.1038/ nature23305.

11. Fogarty NME, McCarthy A, Snijders KE, Powell BE, Kubikova N, Blakeley P, et al. Genome editing reveals a role for OCT4 in human embryogenesis. Nature. 2017 Oct 5; 550 (7674): 67-73. DOI: 10.1038/nature24033.

12. Liang P, Ding C, Sun H, Xie X, Xu Y, Zhang X, et al. Correction of $\beta$-thalassemia mutant by base editor in human embryos. Protein Cell. 2017 Nov; 8 (11): 811-22. DOl: 10.1007/s13238-017-0475-6.

13. Joris H, Nagy Z, Van de Velde H, De Vos A, Van Steirteghem A. Intracytoplasmic sperm injection: laboratory set-up and injection procedure. Hum Reprod. 1998 Apr; 13 Suppl 1: 76-86.

14. Kofiadi IA, Rebrikov DV, Trofimov DY, Alexeev LP, Khaitov RM. Allelic distribution of the CCR5, CCR2, and SDF1 gene polymorphisms associated with HIV-1/AIDS resistance in Russian populations. Dokl Biol Sci. 2007 Jul-Aug; (415): 320-3.

15. Kang X, He W, Huang $Y, Y u$ Q, Chen $Y$, Gao X, Sun X, Fan $Y$. Introducing precise genetic modifications into human 3PN embryos by CRISPR/Cas-mediated genome editing. J Assist Reprod Genet. 2016 May; 33 (5): 581-588. DOI: 10.1007/ s10815-016-0710-8. 